\title{
Effect of Low and High-Dose GABA from Unpolished Rice-Germ on Timing and Quality of Sleep: A Randomized Double-Blind Placebo-Controlled Trial
}

\author{
Yu Yong Shin, Jung-Ick Byun, Sung-Eun Chung, Min-Ji Seong, \\ Han-Ah Cho, Hyun Keuk Cha, Won Chul Shin \\ Department of Neurology, Kyung Hee University College of Medicine, Kyung Hee University Hospital at Gangdong, Seoul, Korea \\ 저용량과 고용량 현미쌀눈 유래 GABA가 수면시간과 질에 미치는 영향에 대한 \\ 무작위 이중 눈가림법 위약 처치시행 연구
}

신유용, 변정익, 정승은, 성민지, 조한아, 차현극, 신원철

경희대학교 의과대학 강동경희대학교병원 신경과학교실

Received December 2, 2016 Revised December 13, 2016 Accepted December 26, 2016

Address for correspondence Won Chul Shin, MD, PhD Department of Neurology, Kyung Hee University Hospital at Gangdong,

892 Dongnam-ro, Gangdong-gu,

Seoul 05278, Korea

Tel: $+82-2-440-6166$

Fax: +82-2-440-7262

E-mail: shin1chul@gmail.com
Objectives: Gamma-aminobutyric acid (GABA) has potential benefits in counteracting the sleep disruption and potential therapeutic effects on blood pressure, stress, cancer, and inflammatory diseases. Recently, High-dose GABA can be extracted from fermented rice germ using lactic acid bacteria. This study aimed to evaluate the effects of GABA natural extracts from fermented rice-germ on sleep latency, subjective sleep quality and insomnia symptoms. Methods: This was a prospective randomized double-blind placebo-controlled trial performed at Kyung-Hee University hospital at Gangdong from June 2013 to October 2013. Adult (age $\geq 30$ ) patients who was diagnosed of insomnia according to DSM-IV criteria was enrolled. They were randomized into three groups: high dose treatment group $300 \mathrm{mg}$; low-dose treatment group, $100 \mathrm{mg}$; and placebo group. Questionnaires including Insomnia Severity Index (ISI), Pittsburgh Sleep Quality Index (PSQI), WHO-5 Well-Being Index were performed, and 1-week actigraphy was recorded before and 1 week after the treatment. Results: Total of 114 patients were randomized into 3 groups: high-dose treatment $(n=37)$, low-dose treatment $(n=38)$, and placebo treatment group $(n=39)$. At 1 week after the treatment, PSQI total score and C2 (sleep latency) score significantly decreased in low-dose and high-dose treatment group than the placebo groups [Repeated measures analysis of variance (ANOVA), $p=0.017,0.004$ respectively]. ISI score also decreased in the two groups in dose-dependent manner (Repeated measures ANOVA, $p=0.037)$. There were five $(4.4 \%)$ patients who reported medication adverse events. Conclusions: This study suggests that treatment of low and high-dose GABA from unpolished rice-germ decreases sleep latency and improve insomnia severity without severe adverse events.

J Sleep Med 2016;13(2):60-66

Key Words: Insomnia, GABA, Unpolished rice, Sleep quality.
서 론

불면증은 잠을 충분히 잘 수 있는 상황임에도 지속적으로 수면개시, 지속시간, 수면구조 통합 및 수면의 질 저하와 함께 주간장애를 일으키는 경우로 정의한다. ${ }^{1}$ 불면증 때문에 생기

This is an Open Access article distributed under the terms of the Creative Commons Attribution Non-Commercial License (http://creativecommons.org/licenses/by-nc/3.0) which permits unrestricted non-commercial use, distribution, and reproduction in any medium, provided the original work is properly cited.
는 주간증상에는 피곤, 기분장애나 예민함, 무기력, 인지기능 저하, 사회생활 장애, 삶의 질 저하 등이 있다. 불면증은 정 신 및 심혈관계 질환의 위험을 증가시킬 뿐 아니라 근긴장 감, 심계항진, 두통, 운전 및 직장내 안전사고 위험을 증가시 킨다. ${ }^{1,2}$ 불면증의 유병률은 전체 인구의 30 50\%이며, 일상 생활능력의 저하까지 동반한 불면증은 10 15\%으로 알려져 있다.1,3, 우리나라에서 불면증의 유병률은 $22.8 \%$ 로 보고되었 으며, ${ }^{5}$ 일반 인구의 약 $70 \%$ 가 최근 한 달간 수면문제가 있는 
것으로 조사되었다. ${ }^{6}$

불면증은 흔한 수면장애임에도 불구하고 적절한 진단과 치료가 되지 못하고 있다. 일반적으로 불면증의 치료는 수면 위생, 수면인지행동치료 등의 비약물치료와 약물치료가 있 지만, 때때로 기존 치료 방법은 경미한 불면증 환자에게 비 용-효율이 낮으며 부담이 될 수 있다.

Gamma-aminobutyric acid(GABA)는 대표적인 억제성 신경전달물질로 벤조다이아제핀 또는 졸피뎀과 같은 수면제 가 흔히 작용하는 $\mathrm{GABA}_{\mathrm{A}}$ 수용체의 효현제로 작용한다. ${ }^{7}$ 발 아현미쌀눈 추출 $\mathrm{GABA}$ 는 동물실험에서 수면의 질 개선, 수면유도효과와 안전성이 검증되었고, ${ }^{8}$ 미국에서는 $\mathrm{GABA}-$ done(Targeted Medical Pharma, LA, USA)이라는 식품으 로 개발되어 수면유도 보조품으로 활용되고 있다. ${ }^{9}$

본 연구는 발아현미쌀눈의 배아발효추출물이 수면에 미치 는 영향과 안전성을 평가하기 위한 무작위배정, 이중맹검, 위약대조군 임상시험이다. 연구의 목적은 1) 위약군에 비해 발아현미쌀눈 발효추출물 투여시에 주관적 수면의 개선을 확인하며, 2) 저용량과 고용량의 발아현미쌀눈 발효추출물 에 따라 수면개선효과의 차이가 있는지 평가하며, 3) 저용량 과 고용량의 발아현미쌀눈 발효추출물의 안전성을 평가하는 것이다.

\section{방 법}

\section{대 상}

2013년 6월부터 10월까지 강동경희대학교병원 수면센터 에 수면에 대한 만족도가 낮아 내원한 자와 모집공고를 내어 수면이력설문지(Sleep History Questionnaire)에 의해 수면의 질 만족도가 낮게 측정된 자를 등록하였다. 등록기준은 1) 연 구시작 1달 내에 DSM-IV 기준에 따라 다음 중 하나 이상의 증상(잠들기 어려움, 수면유지의 어려움, 회복이 되지 않는 수면)을 호소하는 자, 2) 수면이력설문지에 의해 일차성 불면 증(primary insomnia)으로 확인된 자로 하였다. 그 중 1) 다 른 수면질환을 동반한 자, 2) 우울증(라스킨 우울척도 6점 이 상), 3) 불안(코비 불안척도 6점 이상), 4) 인지기능저하(간이 정신상태검사 24점 이하), 5) 3개월 이내 정신작용 약물을 복 용하거나 6) 중증의 질병 기왕력자는 제외하였다.

본 연구는 강동경희대학교병원 임상시험심사위원회(IRB) 의 승인을 받은 시험계획서(IRB 승인번호: 2013-01-037012)에 따라 진행되었고, 식품의약품안전청 및 $\mathrm{ICH}$ 가 정한 임상시험관리기준 $(\mathrm{GCP})$ 에 준하여 실시되었다. 시험의 목적 및 시험약물의 특성은 임상시험대상자에게 설명문을 통해 설명하였으며, 본 시험의 목적 및 위험 등을 알고 동의서를
작성한 지원자만 시험에 참여하였다

\section{발아현미쌀눈 발효추출물}

본 연구는 “바이오벤”에서 개발한 발아현미쌀눈 유래 $\mathrm{GABA}$ 를 사용하였다. 발아현미쌀눈 유래 GABA는 발아현 미쌀눈을 10 배 열수 추출한 추출액에 GABA 생산 유산균인 Lactobacillus sakei B2 16의 생육을 유도하기 위하여 당원 및 질소원으로 설탕 및 효모 추출물을 각각 $4 \%, 2 \%$ 첨가한 후 7\% 수준의 mono sodium glutamate(MSG)를 첨가한 배지 에 L. sakei B2 16을 $1 \%$ 수준으로 접종한 후 $30^{\circ} \mathrm{C}$ 에서 48 시 간동안 배양하였다. 배양된 발효액은 $0.45 \mu \mathrm{m}$ filter(Sartorius, Goettingen, Germany)로 여과한 후 분무건조하여 정량 한 $15 \%$ 로 고농축된 $\mathrm{GABA}$ 시료를 제조하여 사용하였다. 고 용량 발아현미쌀눈 발효추출물은 $300 \mathrm{mg}$ 의 GABA를 함유 하고 있으며, 저용량은 $100 \mathrm{mg}$ 의 $\mathrm{GABA}$ 를 함유하고 있다. 위약과 발아현미쌀눈 발효추출물은 캡슐형태로 제조하여 사용하여 육안으로는 구분할 수 없도록 하였으며, 위약은 인 체에 무해한 maltodextrin을 이용하였다.

임상시험대상자들은 1주간 관찰기간 후, 인터넷 프로그램 (Research Randomizer software; Urbaniak, www.randomizer. org)을 이용하여 도출한 난수표에 따라서 $1: 1: 1$ 의 비율로 배 정하였으며, 배정받은 약물을 평소 수면시간 1 시간 전에 1 주 일간 매일 복용하도록 하였다. 또한 이상반응 기록표를 작성 하게 하여 기재된 이상반응의 종류, 빈도, 정도를 평가하였다.

\section{수면 설문지}

주관적 수면의 질, 불면증 정도와 삶의 질를 평가하기 위하 여 각각 피츠버그수면질지수(Pittsburgh Sleep Quality Index Korean version, PSQI-K), ${ }^{10}$ 불면증심각도지수(Insomnia Severity Index-K, ISI-K)와 세계보건기구 삶의 질 지수 (WHO-5 Well-Being Index 1998 version)를 이용하였다. ${ }^{11,12}$ $\mathrm{PSQI}-\mathrm{K}$ 는 기존 1 달 수면 세부 항목점수를 이용하여 주관 적 수면의 질(component $1, \mathrm{C} 1$ ), 수면잠복(component 2, $\mathrm{C} 2$ ), 수면기간(component 3, C3), 수면효율(component 4, C4), 수면방해(component 5, C5), 수면약물이용(component 6, C6)과 주간기능장애(component 7, C7)를 평가하였다. ISI 는 입면과 수면지속의 어려움, 수면의 조기종결로 구성된 평 가문항을 가지고 있으며, 문항당 0 4점으로 28점 만점에 점 수가 높을수록 심한 불면을 의미한다. ${ }^{13}$ 매일 아침 기상 후 “지난 밤 잠자리에 대하여 어떻게 느끼십니까?”, 그리고 잠 자리 들기 전 “오늘 낮에 대해 어떻게 느끼십니까?”라는 질 문에 대한 평가를 "매우 안 좋다"에서 "매우 좋다"까지 총 5 단계로 대답하도록 하였으며, 마지막 3일간의 낮(quality of 
day)과 밤(quality of night)에 대한 점수를 각각 평균하여 주 관적인 수면만족도를 평가하였다. 임상시험 대상자들은 위 설문지를 연구등록 시, 1 주일간 약물 복용 후 두 차례 작성 하였다.

\section{수면일지와 활동측정기}

약물 복용 전 1주일 동안, 그리고 약물 복용하며 1주일간 매일 수면일지를 작성하고 활동측정기(actigraphy)를 착용 하도록 하여 수면행태를 확인하였다. 활동측정기는 MiniMotionlogger Actigraph(Ambulatory Monitoring, Inc., Ardsley, NY, USA) 제품을 이용하였으며, 수면일지와 비교 분 석하여 수면잠복기, 총 수면시간(잠자리에 누워 있는 총 시 간-수면잠복기-수면 중 각성시간), 수면효율(총 수면시간/ 잠자리에 누워있는 총 시간 $\times 100)$ 을 계산하였다. 임상시험 약물 복용 전 7일, 복용 후 7일간 착용한 활동측정기(actigraphy) 결과를 통해 수면잠복시간과 총 수면시간, 수면효율을 분석하였다. 활동측정기 분석은 각 7일간의 기록 중 최대값 과 최소값을 제외한 5일간의 기록의 평균치를 이용하여 발 아현미쌀눈 발효추출물의 수면개선효과를 분석하였다

\section{통계방법}

피험자의 일반적 특성은 실수와 백분율을 사용하였고 군 간의 차이는 one-way analysis of variance(ANOVA)와 chisquare test를 사용하여 분석하였으며 약물치료 전후 그룹 내 차이는 paired t-test를 이용하였다. 임상시험약물 투여군에 따라 투여 전후 수면에 미치는 영향의 차이는 개체 내 요소를 약물 투여 전후 시간, 개체 간 요소를 약물 그룹으로 설정한 반복측정분산분석(repeated-measure ANOVA)을 시행한 후, 그룹과 시간 사이에 유의한 교호작용이 있는지 여부에 따라 판정하였다. 유의한 교호작용이 있을 경우, 약물 투여 전후 값의 차이가 그룹 간에 유의하게 다른지 ANOVA 분석을 통 해 검증하였으며, 피셔의 최소유의차검정(least significant difference) 방법을 이용해 사후분석을 시행하였다. 통계 분 석은 SPSS version 12.0(SPSS Inc., Chicago, IL, USA)을 이 용하였고 $p$ 값이 0.05 미만인 경우 통계적으로 유의한 것으 로 판정하였으며, 사후분석에서는 bonferonni 교정한 $p$ 값이 0.017 미만인 경우를 유의한 것으로 판정하였다.

Table 1. Baseline insomnia characteristics of high dose and low dose GABA, and control group

\begin{tabular}{|c|c|c|c|c|}
\hline & Placebo $(n=39)$ & 150 mg GABA $(n=37)$ & 300 mg GABA $(n=38)$ & $p$-value \\
\hline Age (years) & $56.1 \pm 13.3$ & $55.7 \pm 13.8$ & $54.4 \pm 11.6$ & 0.837 \\
\hline Sex (Male:Female) & $11: 28$ & $8: 29$ & $9: 29$ & 0.791 \\
\hline \multicolumn{5}{|l|}{ Questionnaire } \\
\hline PSQI-K total score & $11.77 \pm 1.90$ & $12.16 \pm 1.93$ & $11.58 \pm 1.98$ & 0.417 \\
\hline C1 (sleep quality) & $2.03 \pm 0.58$ & $1.86 \pm 0.42$ & $1.84 \pm 0.50$ & 0.225 \\
\hline C2 (sleep latency) & $2.13 \pm 0.89$ & $2.51 \pm 0.69$ & $2.32 \pm 0.81$ & 0.118 \\
\hline C3 (total sleep time) & $2.82 \pm 0.39$ & $2.92 \pm 0.28$ & $2.84 \pm 0.44$ & 0.490 \\
\hline C4 (sleep efficacy) & $2.05 \pm 1.03$ & $2.14 \pm 0.98$ & $1.97 \pm 1.05$ & 0.791 \\
\hline C5 (sleep disorders) & $1.00 \pm 0.23$ & $1.00 \pm 0.33$ & $1.00 \pm 0.27$ & 1.00 \\
\hline C6 (use of sleeping pill) & 0 & 0 & 0 & - \\
\hline C7 (sleep related dysfunction) & $1.74 \pm 0.85$ & $1.73 \pm 1.07$ & $1.61 \pm 1.08$ & 0.803 \\
\hline ISI-K & $13.95 \pm 4.37$ & $14.35 \pm 5.04$ & $14.08 \pm 3.32$ & 0.917 \\
\hline WHO-5 Index & $11.05 \pm 3.88$ & $12.08 \pm 5.35$ & $11.34 \pm 4.59$ & 0.611 \\
\hline QON & $8.41 \pm 1.98$ & $8.81 \pm 1.75$ & $8.58 \pm 1.59$ & 0.618 \\
\hline QOD & $8.26 \pm 1.80$ & $8.49 \pm 2.18$ & $8.53 \pm 1.72$ & 0.799 \\
\hline \multicolumn{5}{|l|}{ Actigraphy } \\
\hline Sleep latency (min) & $45.13 \pm 36.32$ & $60.27 \pm 44.25$ & $47.50 \pm 32.67$ & 0.182 \\
\hline Total sleep time (min) & $260.0 \pm 59.74$ & $247.3 \pm 67.2$ & $266.05 \pm 55.0$ & 0.399 \\
\hline Sleep efficacy (\%) & $66.60 \pm 16.66$ & $63.74 \pm 17.42$ & $66.12 \pm 15.09$ & 0.722 \\
\hline
\end{tabular}

Numbers are mean \pm standard deviation, one-way analysis of variance. GABA: gamma-aminobutyric acid, PSQI-K: Pittsburgh Sleep Quality Index Korean version, ISI-K: Insomnia Severity Index-K, WHO-5 Index: Well-Being Index 1998 version, QON: quality of night, QOD: quality of day 


\section{결 과}

\section{연구대상자의 특성}

총 133 명이 본 시험에 등록하였으나, 이 중 15 명은 선정기
준에 맞지 않아서 제외하였으며, 4 명은 1 주 관찰기간 중 동 의 철회하여 제외되었다. 총 114 명이 시험을 완료하였고, 이 들의 평균 나이는 55.5세였고 여성이 86명(75.4\%)으로 더 많 았다. PSQI-K 점수는 평균 11.85점으로 수면의 질이 저하

Table 2. Efficacy of short-term treatment with placebo, low dose and high dose GABA group on promoting sleep

\begin{tabular}{|c|c|c|c|c|c|}
\hline & Placebo $(n=39)$ & 150 mg GABA $(n=37)$ & 300 mg GABA $(n=38)$ & $\mathrm{F}$ & $p^{*}$ \\
\hline \multicolumn{6}{|l|}{ PSQI-K } \\
\hline Total & & & & 2.42 & 0.017 \\
\hline Pre & $11.77 \pm 1.90$ & $12.16 \pm 1.93$ & $11.58 \pm 1.98$ & & \\
\hline Post & $10.28 \pm 2.70^{\dagger}$ & $9.00 \pm 3.00^{\dagger}$ & $9.21 \pm 2.78^{\dagger}$ & & \\
\hline C1 (sleep quality) & & & & 0.005 & 0.995 \\
\hline Pre & $2.03 \pm 0.58$ & $1.86 \pm 0.42$ & $1.84 \pm 0.50$ & & \\
\hline Post & $1.44 \pm 0.68^{\dagger}$ & $1.27 \pm 0.65^{\dagger}$ & $1.24 \pm 0.43^{\dagger}$ & & \\
\hline C2 (sleep latency) & & & & 5.75 & 0.004 \\
\hline Pre & $2.13 \pm 0.89$ & $2.51 \pm 0.69$ & $2.32 \pm 0.81$ & & \\
\hline Post & $1.97 \pm 0.87$ & $1.73 \pm 1.15^{\dagger}$ & $1.87 \pm 0.91^{\dagger}$ & & \\
\hline C3 (total sleep time) & & & & 1.07 & 0.345 \\
\hline Pre & $2.82 \pm 0.39$ & $2.92 \pm 0.28$ & $2.84 \pm 0.44$ & & \\
\hline Post & $2.56 \pm 0.68^{\ddagger}$ & $2.43 \pm 0.77^{\dagger}$ & $2.39 \pm 0.86^{\dagger}$ & & \\
\hline C4 (sleep efficacy) & & & & 1.40 & 0.251 \\
\hline Pre & $2.05 \pm 1.03$ & $2.14 \pm 0.98$ & $1.97 \pm 1.05$ & & \\
\hline Post & $1.64 \pm 1.01^{\ddagger}$ & $1.35 \pm 1.16^{\dagger}$ & $1.34 \pm 1.10^{\dagger}$ & & \\
\hline C5 (sleep disorders) & & & & 0.33 & 0.717 \\
\hline Pre & $1.00 \pm 0.23$ & $1.00 \pm 0.33$ & $1.00 \pm 0.27$ & & \\
\hline Post & $1.00 \pm 0.23$ & $0.97 \pm 0.16$ & $0.95 \pm 0.23$ & & \\
\hline C6 (use of sleeping pills) & & & & - & - \\
\hline Pre & 0 & 0 & 0 & & \\
\hline Post & 0 & 0 & 0 & & \\
\hline C7 (sleep related dysfunction) & & & & 1.46 & 0.238 \\
\hline Pre & $1.74 \pm 0.85$ & $1.73 \pm 1.07$ & $1.61 \pm 1.08$ & & \\
\hline Post & $1.67 \pm 0.77$ & $1.44 \pm 1.07$ & $1.42 \pm 0.83$ & & \\
\hline ISI-K & & & & 3.39 & 0.037 \\
\hline Pre & $13.95 \pm 4.37$ & $14.35 \pm 5.04$ & $14.08 \pm 3.32$ & & \\
\hline Post & $11.74 \pm 4.90^{\dagger}$ & $10.81 \pm 4.70^{\dagger}$ & $9.16 \pm 3.15^{\dagger}$ & & \\
\hline WHO-5 Index & & & & 0.52 & 0.593 \\
\hline Pre & $11.05 \pm 3.88$ & $12.08 \pm 5.35$ & $11.34 \pm 4.59$ & & \\
\hline Post & $12.64 \pm 4.37^{\ddagger}$ & $13.08 \pm 4.44$ & $13.47 \pm 4.27^{\dagger}$ & & \\
\hline QON & & & & 0.56 & 0.568 \\
\hline Pre & $8.41 \pm 1.98$ & $8.81 \pm 1.74$ & $8.58 \pm 1.58$ & & \\
\hline Post & $9.54 \pm 1.89^{\dagger}$ & $9.70 \pm 1.37^{\dagger}$ & $9.97 \pm 1.52^{\dagger}$ & & \\
\hline QOD & & & & 0.17 & 0.843 \\
\hline Pre & $8.26 \pm 1.80$ & $8.49 \pm 2.18$ & $8.53 \pm 1.72$ & & \\
\hline Post & $9.36 \pm 1.89^{\dagger}$ & $9.84 \pm 1.68^{\ddagger}$ & $9.89 \pm 1.77^{\dagger}$ & & \\
\hline
\end{tabular}

Numbers are mean \pm standard deviation. ${ }^{*} p$-value for repeated measured analysis of variance time (pre, post) $\times$ group interaction; paired- $t$ test was performed for each group, ${ }^{\dagger} p<0.01,{ }^{\ddagger} p<0.05$. GABA: gamma-aminobutyric acid, PSQI-K: Pittsburgh Sleep Quality Index Korean version, ISI-K: Insomnia Severity Index-K, WHO-5 Index: Well-Being Index 1998 version, QON: quality of night, QOD: quality of day 
되어 있었으며 ISI-K 점수도 평균 14.12점으로 주관적 불면 이 있었다. 활동측정기 결과 평균 수면시간은 257.9분이었 고, 수면잠복기는 평균 65.5 분, 수면효율은 평균 $50.8 \%$ 로 잘 자지 못하였다. 대상자는 무작위적으로 위약군 39명, 저용량 의 발아현미쌀눈 발효추출물군 $(100 \mathrm{mg}) 37$ 명, 고용량의 발아 현미쌀눈 발효 추출물군 $(300 \mathrm{mg}) 38$ 명으로 배정되었고 1주 일간 해당 임상약물을 복용하였다.

세 군 간의 나이, 성별은 차이가 없었으며, 초기 설문지 결 과 유의한 차이가 없었다. 또한 피츠버그수면질지수(PSQI$\mathrm{K})$ 의 세부항목에서도 세 군 간 유의한 차이는 없었다. 활동 측정기 결과 수면잠복기, 총 수면시간, 수면효율에서도 군 간 차이가 없었다(Table 1).

\section{약물 투여 전후 수면 설문지 점수 변화}

약물 투여 전후 고용량 GABA 치료군에서는 모든 수면 설문점수가 호전되었으며, 저용량 $\mathrm{GABA}$ 군에서도 $\mathrm{WHO}-5$ Index를 제외한 모든 점수에서 통계적으로 유의한 호전이 있 었다. 위약군에서도 약물 투여 후 설문 점수의 호전이 있었으 나, PSQI-K 세부항목 $\mathrm{C} 2$ 에서는 유의한 차이가 없었다.
PSQI-K 전체 점수 $[\mathrm{F}(2,111)=2.42, p=0.017]$ 와 그 세부항 목인 $\mathrm{C} 2[\mathrm{~F}(2,111)=5.752, p=0.004]$, 그리고 ISI-K 점수[F $(2,111)=3.396, p=0.037]$ 에서 약물 투여 전후 시간과 투여 약 물그룹에서 유의한 교호작용이 관찰되었다. 약물 투여 전후 PSQI-K 전체 점수와 세부항목 C2 점수의 변화는 치료군에 서 위약군에 비해 더 컸으며(PSQI-K 전체 $-3.16 \pm 2.4$ vs. $-1.49 \pm 2.4$, post - hoc $p=0.004$, C2 점수 $-0.78 \pm 0.89$ vs. $-0.15 \pm 0.63$, post $-\mathrm{hoc} p=0.001)$, 고용량군과 저용량군 간 차 이는 없었다. ISI-K 점수 변화는 고용량 치료군만 위약군에 비해 더 컸으며 $(-4.92 \pm 4.36$ vs. $-2.21 \pm 5.02$, post $-\mathrm{hoc} p=$ $0.010)$, 저용량 치료군은 위약군과 유의한 차이가 없었다 (Table 2, Fig. 1).

\section{약물 투여 전후 활동측정기 결과 변화}

위약군에서는 치료 전후 총 수면시간이 증가하였으나, 수 면잠복기, 수면효율은 유의한 차이가 없었다. 반면에 GABA 치료군은 저용량, 고용량 모두에서 유의하게 총 수면시간이 증가하였고, 수면 잠복기가 감소하였으며, 수면효율이 증가 하였다. 하지만 그룹 간 수면잠복시간, 총 수면시간, 수면효
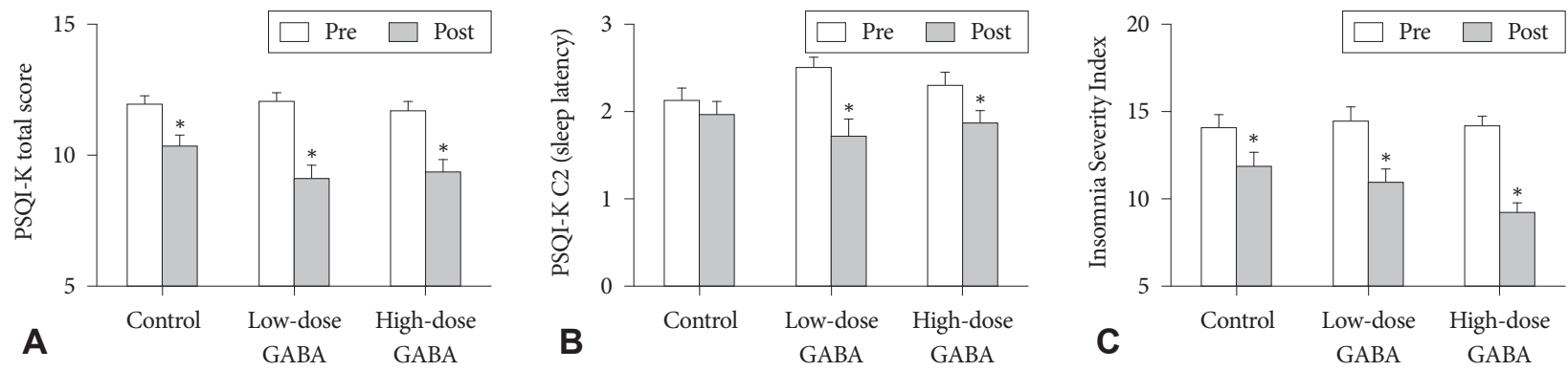

Figure 1. Sleep questionnaire score changes in placebo group, low dose and high dose GABA treatment group. (A) Pittsburgh Sleep Quality Index Korean version (PSQI-K) total score. (B) PSQI-K component 2 score (Sleep latency). (C) Insomnia Severity Index (ISI). GABA treatment group showed significant reduction in PSQI-K and PSQI-K C2 score after the treatment. ISI score significantly improved only in high-dose GABA treatment group. ${ }^{*} p$ value $<0.05$ for paired $t$-test in each treatment groups. PSQI-K: Pittsburgh Sleep Quality Index Korea version, C2: component 2 (sleep latency), GABA: gamma-aminobutyric acid.

Table 3. Comparison with placebo, low dose and high dose GABA group on sleep promotion effect by using actigraphy

\begin{tabular}{|c|c|c|c|c|c|}
\hline & Placebo $(n=39)$ & $150 \mathrm{mg}$ GABA $(\mathrm{n}=37)$ & 300 mg GABA $(n=38)$ & $\mathrm{F}$ & $p^{*}$ \\
\hline SL & & & & 1.85 & 0.162 \\
\hline Pre & $45.13 \pm 36.32$ & $60.27 \pm 44.25$ & $47.50 \pm 32.67$ & & \\
\hline Post & $37.74 \pm 33.35$ & $36.49 \pm 33.68^{\dagger}$ & $30.92 \pm 17.66^{\dagger}$ & & \\
\hline TST & & & & 0.89 & 0.413 \\
\hline Pre & $260.0 \pm 59.74$ & $247.3 \pm 67.2$ & $266.05 \pm 55.0$ & & \\
\hline Post & $298.5 \pm 62.7^{\dagger}$ & $305.1 \pm 73.1^{\dagger}$ & $314.0 \pm 61.6^{\dagger}$ & & \\
\hline SE & & & & 1.96 & 0.146 \\
\hline Pre & $66.60 \pm 16.66$ & $63.74 \pm 17.42$ & $66.12 \pm 15.09$ & & \\
\hline Post & $71.34 \pm 12.05$ & $74.11 \pm 14.78^{\dagger}$ & $76.06 \pm 13.34^{\dagger}$ & & \\
\hline
\end{tabular}

Numbers are mean \pm standard deviation. ${ }^{*} p$-value for repeated measured analysis of variance time (pre, post) $\times$ group interaction; paired- $t$ test was performed for each group, ${ }^{\dagger} p<0.01$. GABA: gamma-aminobutyric acid, SL: sleep latency, TST: total sleep time, SE: sleep efficacy 
율은 통계적으로 유의한 차이가 없었다(Table 3).

\section{약물 안전성}

본 연구에 참여한 114 명의 임상시험대상자 중에서, 5 명이 약물 복용 후 복부 불편감(3명), 열감(1명), 속 쓰림(1명)을 보 고하였다. 복부 불편감은 저용량 비배아발효추출물군 $(\mathrm{n}=37)$ 에서 1 명, 고용량 발아현미쌀눈 발효추출물군 $(\mathrm{n}=38)$ 에서 2 명 이 보고하였으며, 속 쓰림과 열감은 각각 저용량 비배아발효 추출물군에서 한 명씩 보고하였다.

\section{고 찰}

본 연구에서는 발아현미쌀눈 발효추출물의 수면의 질 개 선효과를 확인하기 위해서 실험군과 대조군으로 무작위배 정, 이중눈가림연구로 진행하였다. 연구 결과 발아현미쌀눈 발효추출물을 1 주간 수면 전에 복용하였을 때 위약군에 비해 서 수면잠복시간을 더 줄이고, 주관적 수면의 질 및 불면증상 을 개선되는 것이 확인되었다. 수면잠복시간과 주관적 수면 의 질은 발아현미쌀눈 발효추출물을 복용하였을 때 유의한 개선이 관찰되었으며, 불면증상은 고용량 $(300 \mathrm{mg})$ 을 복용하 였을 때 더 큰 효과가 있었다. 특히, 발아현미쌀눈의 수면효 과에 대한 본 연구는 이전 국내에서 시행된 적이 없으며, 실 제 1 달 이상의 불면증 증상을 가지는 환자들을 대상으로 한 결과로 그 의의가 높다.

현재 경증의 불면증 환자에서 적절한 수면치료 방법은 부 족한 실정이다. 수면인지행동치료는 비교적 안전하고 장기 간 치료효과를 기대할 수 있으나. ${ }^{7}$ 비용이 비싸고 전문가가 개입해야 하며, 치료효과가 나타나는 데 시간이 오래 걸리는 한계가 있다. ${ }^{8}$ 약물 치료는 단기적으로 효과가 있으나 장기적 으로 사용할 경우 습관화가 생길 수 있으며, 금단증상을 일으 킬 수 있다. 910 따라서 심각한 만성불면증은 약물치료와 수면 인지행동치료의 병행이 필요하지만, 일시적이거나 경증의 불면증 환자에서는 비록 효과가 적더라도 비용이 적게 들면 서도 쉽고, 안전하게 시행할 수 있는 치료법이 필요하다.

신경계통물질인 $\mathrm{GABA}$ 는 중추신경계에서 억제성 아미노 산으로, 포유류의 중추신경계에 필수구성요소이다. GABAreceptors가 뇌조직에 주로 존재하고 신경전달물질인 $\mathrm{GABA}$ 가 리간드로 작용하여 결합되어 중추신경계에서 억제성 신 경전달물질로서 작용하며, $\mathrm{GABA}$ 의 양이 증가되면 전형적 으로 정서적 안정과 항정신불안증, 항경련 효과, 수면유도 및 수면유지를 나타낸다. 또한 시상하부에서 외배측전시각 교차핵(ventrolateral preoptic nucleus)이 활성화되면서 다 량으로 분비된 GABA가 뇌의 여러 각성 중추를 억제함으로
써 잠을 자게 된다. 따라서 $\mathrm{GABA}$ 계열의 물질은 수면 잠복 시간을 짧게 하고, 수면시간은 연장되어서, 대부분의 수면제 약물들은 GABA계열의 약물들이다. ${ }^{7}$

$\mathrm{GABA}$ 는 일반곡류에 흔히 존재하지만, 그 함량은 일반미 에 1 40 mg/100 g, 현미에 4 8 mg/100 g, 발아현미쌀눈에 $10 \sim 100 \mathrm{mg} / 100 \mathrm{~g}$ 으로 극히 적어 수면에 미치는 영향은 자연 상태에서 거의 없다. 최근 $\mathrm{MSG}$ 를 $\mathrm{GABA}$ 로 전환시키는 김 치, 젓갈 등의 젖산균을 비롯해 Lactobacillus brevis와 Latococcus lactis 등의 유산균을 이용하여 쌀 및 콩을 발효시 키면 250 700 mg/100 g의 고농도로 GABA를 생산할 수 있 다고 보고되면서 식물체에서 추출한 $\mathrm{GABA}$ 를 활용할 수 있 게 되었다. 본 연구에서 사용한 발아현미쌀눈 발효추출물은 현미쌀눈추출물에 유산균인 Lactobacillus sakei B2 16을 배양한 고농도 $\mathrm{GABA}$ 를 함유한 발효물로 수면유도와 수면 유지 효과를 보이는 것으로 생각할 수 있다.

본 연구에서는 PSQI-K의 총점뿐 아니라 세부항목 점수를 이용하여 수면의 질, 수면잠복시간, 총 수면시간, 수면효율을 평가하였다. 발아현미쌀눈 발효추출물 복용군에서 위약군 에 비해 치료 후 PSQI-K 총점과 수면잠복시간을 나타내는 $\mathrm{C} 2$ 항목 점수의 감소가 더 크게 나타났는데, 이는 발아현미 쌀눈 발효추출물이 주관적 수면의 질 개선뿐 아니라 수면유 도효과를 가지고 있음을 나타내는 결과이다. GABA 치료의 수면잠복기 감소효과는 활동측정기 분석에서도 확인할 수 있었다. 그룹 간 유의한 통계적 차이는 없었으나, 약물 복용 전후 위약군에서는 수면잠복시간의 변화는 없었던 반면에 $\mathrm{GABA}$ 투여군에서는 유의하게 수면잠복기 감소가 관찰되 었다. 유사한 방법으로 외국에서 출시된 GABAdone을 이용 한 무작위성 임상시험결과에서도 본 연구와 같이 설문지 결 과 수면잠복기가 감소되었고, 수면의 질이 향상되었다. 또한 24시간 심박동 변이를 분석한 결과 부교감신경활성이 약물 치료군에서 증가되었음을 확인하였으며, 이것이 수면 향상 의 기전으로 설명되었다. ${ }^{9}$

위약을 투여한 대조군에서도 수면 설문지 점수의 유의한 감소가 나타났기 때문에 placebo 효과가 주관적 수면에 중요 한 역할을 함을 확인할 수 있었다. 하지만, 주관적인 불면 정 도를 나타내는 ISI-K와 전반적인 수면의 질을 반영하는 $\mathrm{PSQI}-\mathrm{K}$ 점수에서는 그 감소 정도가 위약군에 비해 치료군 에서 유의하게 컸기 때문에, GABA 복용이 불면증 개선에 효과가 있음을 확인할 수 있었다.

본 연구는 국내에서 처음으로 발아현미쌀눈에서 추출한 $\mathrm{GABA}$ 가 수면에 미치는 영향을 평가한 연구로 그 의의가 있 으나 몇 가지 한계점을 고려하여야 한다. 단일기관 연구로 선 택편향의 위험성이 있으며, 치료효과를 1 주일만 평가하여 기 
간이 짧았다. PSQI-K는 원래 1달의 수면을 평가하는 설문지 로 1주일 수면의 질을 평가하기에 한계가 있으나, 연구에 따 라서는 1 3주의 수면의 질을 평가하기 위한 목적으로 사용 하였다. ${ }^{14-16}$ 일주일간 복용할 때는 발아현미쌀눈 추출 GABA 의 부작용이 거의 없었으나, 장기간 사용하였을 때의 효과와 부작용에 대한 평가는 이루어지지 못하였기 때문에 향후 이 에 대한 추가적인 연구가 필요하다. 또한 손목의 착용하는 활 동측정기는 지속적으로 움직임이 있으면 깨어 있는 것으로, 지속적으로 움직이지 않으면 수면으로 인식하는 알고리즘 을 가지고 있기 때문에, 잠자지 않더라도 가만히 있으면 수면 으로 인식할 수 있다. 따라서 정확한 수면잠복기 평가를 위해 서는 향후 수면다원검사를 통한 추가적인 연구 또한 필요할 것으로 생각된다.

발아현미쌀눈 발효추출물의 수면개선효과를 확인하기 위 해서 위약군과 저용량군과 고용량군으로 무작위배정, 이중 눈가림연구로 진행한 본 연구에서는 발아현미쌀눈 발효추출 물은 수면유도 효과가 있으며 안전하게 사용할 수 있음을 확 인하였다.

\section{REFERENCES}

1. Schutte-Rodin S, Broch L, Buysse D, Dorsey C, Sateia M. Clinical guideline for the evaluation and management of chronic insomnia in adults. $J$ Clin Sleep Med 2008;4:487-504.

2. Silber MH. Clinical practice. Chronic insomnia. N Engl J Med 2005; 353:803-810.

3. Ohayon MM. Epidemiology of insomnia: what we know and what we still need to learn. Sleep Med Rev 2002;6:97-111.

4. National Institutes of Health. National institutes of health state of the science conference statement on manifestations and management of chronic insomnia in adults, June 13-15, 2005. Sleep 2005;28:1049-1057.

5. Cho YW, Shin WC, Yun CH, Hong SB, Kim J, Earley CJ. Epidemiology of insomnia in Korean adults: prevalence and associated factors. J Clin Neurol 2009;5:20-23.

6. Woo JM, Hyun SY, Lee SH, et al. Productivity time lost by sleep disturbance among workers in Korea. J Korean Neuropsychiatr Assoc 2011; 50:62-68.

7. Gottesmann C. GABA mechanisms and sleep. Neuroscience 2002;111: 231-239.

8. Mabunga DF, Gonzales EL, Kim HJ, Choung SY. Treatment of GABA from fermented rice germ ameliorates caffeine-induced sleep disturbance in mice. Biomol Ther (Seoul) 2015;23:268-274.

9. Shell W, Bullias D, Charuvastra E, May LA, Silver DS. A randomized, placebo-controlled trial of an amino acid preparation on timing and quality of sleep. Am J Ther 2010;17:133-139.

10. Sohn SI, Kim DH, Lee MY, Cho YW. The reliability and validity of the Korean version of the Pittsburgh Sleep Quality Index. Sleep Breath 2012; 16:803-812.

11. Cho YW, Song ML, Morin CM, et al. Validation of a Korean version of the insomnia severity index. J Clin Neurol 2014;10:210-215.

12. Hauri PJ. Cognitive deficits in insomnia patients. Acta Neurol Belg 1997;97:113-117.

13. Cho YW, Song ML, Morin CM. Validation of a Korean version of the Insomnia Severity Index. J Clin Neurol 2014;10:210-215.

14. Tu JH, Chung WC, Yang CY, Tzeng DS. A comparison between acupuncture versus zolpidem in the treatment of primary insomnia. Asian J Psychiatr 2012;5:231-235.

15. Kim SJ, Lee YJ, Lee YJ, Cho SJ. Effect of quetiapine XR on depressive symptoms and sleep quality compared with lithium in patients with bipolar depression. J Affect Disord 2014;157:33-40.

16. Wade AG, Crawford G, Ford I, et al. Prolonged release melatonin in the treatment of primary insomnia: evaluation of the age cut-off for short- and long-term response. Curr Med Res Opin 2011;27:87-98. 